\title{
Induction and Mentoring of Beginning Secondary School Teachers: A Case Study
}

\author{
Jared Keengwe** \& Emmanuel Adjei-Boateng* \\ Department of Teaching and Learning, University of North Dakota
}

231 Centennial Drive BOX 7189, Grand Forks, ND 58202, United States

Tel: 1-701-777-3189**; 1-701-777-3153*

E-mail: jared.keengwe@email.und.edu**; emmanuel.adjeiboaten@my.und.edu*

\author{
Received: February 16, 2012 Accepted: March 21, 2012 Published: June 25, 2012 \\ doi:10.5296/ije.v4i2.1402 URL: http://dx.doi.org/10.5296/ije.v4i2.1402
}

\begin{abstract}
The purpose of this study was to examine the experiences of beginning secondary school teachers in Ghana: their challenges, induction process, and the support available for them, and identify the need for a formal induction and mentoring policy for beginning teachers. Beginning secondary school teachers reported many challenges including delayed payment of salaries, problems with classroom management and assessment, and inadequate learning materials. The findings suggest that beginning teachers were not properly inducted into the teaching profession. Therefore, there is need for the government to create formal induction and mentoring policy for beginning teachers.
\end{abstract}

Keywords: induction; mentoring; secondary school teachers; teacher attrition; teacher retention 


\section{Introduction}

A significant mark of the teaching profession is its ability to ensure the smooth transition and success of its new entrants by bridging the gap between classroom learning and actual field practice. Beyond the initial excitement of joining the teaching profession, beginning teachers generally experience multiple challenges related to the profession. The discrepancy between their vision of teaching and the reality on the ground makes things more difficult than they had anticipated. They are normally burdened with difficult assignments that experienced teachers reject (Podsen, \& Denmark, 2000). However, some new teachers hide their problems since they are either unable to seek help or consider asking for help as a sign of mediocrity.

Although every profession experiences attrition of some of its new entrants, the rate among beginning teachers is unprecedented (Ingersoll, \& Smith, 2004). Reportedly, about one-third of beginning teachers leave their schools after the first year (Eaton, \& Sisson, 2008) while about half of all beginning teachers are lost to the profession within the first 5 years (Ingersoll \& Smith, 2004; Eaton, \& Sisson, 2008). The mentality that college education for teachers is enough for the novice teachers to be successful is contrary to the reality (Odell \& Huling, 1998). With lack of support identified as the most frequently cited concern for why many teachers leave the profession (American Federation of Teachers-AFT, 2001), critics have classified teaching as a profession that consumes its young ones (Ingersoll \& Smith, 2004).

\section{Beginning Teacher Induction and Mentoring}

Since teacher development occurs in stages (Odell \& Huling, 1998) the survival of the fittest approach is unsuitable for the success and retention of beginning teachers. Consequently, educational administrators in many parts of the United States and other developed countries have adopted induction and mentoring programs for beginning teaching. There is a growing interest in this form of support, guidance and orientation for novice teachers (Ingersoll \& Smith, 2004). However, for mentoring programs to be successful in accomplishing their primary goal of supporting and guiding beginning teachers, they should be integrated into the larger framework of the induction process for the beginning teachers. The components essential for a successful mentoring of beginning teachers include: Program Purpose and Rationale; Mentor Selection and Mentor/Novice Matching; Mentor Teacher Preparation and Development; Mentor Roles and Practices; Program Administration, Implementation, and Evaluation; and School, District, and University Cultures and Responsibilities (Odell, 2006).

Induction and mentoring are necessary to help beginning teachers to succeed in their first years and remain in the profession as well as beginning teachers who are provided with support, are less likely to leave their schools and the noble profession (AFT, 2001; Ingersoll $\&$ Smith, 2004). There has been a growth of teacher mentoring and induction programs in recent years and that a large percentage of new teachers participate in some kind of program (American Association of State Colleges and Universities, 2006). Unfortunately, formal induction and mentoring practices for beginning teachers are not common in many 
educational systems across the globe.

\section{Education in Ghana}

Ghana is a developing country with a primary commitment and efforts to provide formal education to its children and youth. In Ghana as in many developing countries, education is viewed as the key to sustainable development. Ghana is committed through article 25 of the 1992 republican constitution to ensuring equal access of education for all children. Primary elementary education is free and compulsory for all up to the junior high school level. All elementary students, including those in private schools are provided with free textbooks by the government. Currently, free lunch and school uniforms are provided on pilot basis for pupils in selected school districts. These interventions have raised enrolment and retention in the elementary schools (Lewin \& Stuart, 2003).

To meet the growing demand of education for all, government has been improving school infrastructure and providing other things needed for teaching and learning. But in developing countries like Ghana, where technology may be lacking and infrastructure is inadequate, the most significant factor in education is the teacher. Quality teachers make great impact on students learning in diverse ways (Alliance for Excellent Education, 2006). Levin, Belfield, Muennig, and Rouse (2007) correctly argue that "an individual's educational attainment is one of the most important determinants of their life chances in terms of employment, income, health status, housing, and many other amenities" (p. 2). Therefore, the increasing demand for public education calls for training, recruitment and retention of more qualified teachers.

\section{Teacher Shortage}

There is a general shortage of teachers in Ghana. The government has to increase its output of trained teachers to about three or four times if all children attending primary schools in Ghana were to be taught by trained teachers (Lewin \& Stuart, 2003). Further, this situation is aggravated by a 5 percent primary teacher attrition rate (Lewin \& Stuart, 2003). The challenge of teacher supply is even greater at the senior secondary level where there is need for subject specializations (Mulkeen, Chapman, DeJaeghere, \& Leu, 2007). The situation is the worst among secondary schools in the deprived communities. The increasing demand for trained secondary education teachers is defeated by secondary teacher attrition, issues with teacher preparation, and perceived unattractive conditions of service (Mulkeen, et al., 2007).

Ghana, like most developing nations, has yet to establish a formal educational policy on induction and mentoring for beginning teachers (Cobbold, 2007). At the secondary level, schools, districts and regions hardly offer any organized orientation for the beginning teachers. Additionally, there is no formal induction and mentoring program available for new and beginning teachers. In many developing countries such as Ghana, the initiation of beginning teachers is usually a try and error experience (Ingersoll \& Smith, 2004). Therefore, state-level teacher induction and mentoring programs are highly needed to help beginning teachers as well as to enhance teacher retention in the profession (American Association of 
State Colleges and Universities, 2006).

\section{The Focus of Our Research}

The purpose of this study was to examine the experiences of beginning secondary school teachers in Ghana: their challenges, induction process, and support available for them, and identify the need for a formal induction and mentoring policy for beginning teachers.

The following research questions guided the study:

(a) What challenges do beginning secondary school teachers face in Ghana?

(b) How are beginning secondary school teachers in Ghana inducted into the profession?

(c) What kind of support is provided to beginning secondary school teachers in Ghana?

\section{The Method}

\subsection{Sample Selection}

Beginning secondary school teachers in Ghana constituted the targeted population for this study. For the purpose of this study, beginning teachers refers to all secondary school teachers who had taught for less than four years after graduation from university or college. A total of 30 beginning teachers were sampled from six secondary schools in three school districts in one region. Purposive sampling was used because a participant needed to be a beginning high school teacher.

\subsection{Instrument}

Questionnaire and phone interviews were used to gather data for the study. Questionnaire was appropriate since this research dealt with teachers, who were able to respond to text items. It was economical and efficient in collecting data, and ensured the anonymity of respondents (Patten, 2001). The questionnaire contained two parts. The first part covered demographics and the second part covered issues in the research questions: challenges of beginning secondary school teachers, induction experiences and support available for novice teachers. Analysis of data was accomplished through coding, constant comparison and descriptive statistics. Responses were typed and read through four times, coded, and compared for similarities and differences. Descriptive statistics was also used to make sense of the data.

\subsection{Limitations}

The study was limited in scope of the regions covered. Ideally, the study should have covered many schools from different school districts and regions. However, the researchers lacked the resources accomplish this. A broad coverage could have resulted to a fairer assessment of the entry experiences of beginning secondary teachers. Schools in Ghana also share common school practices, resulting to a lack of divergent ideas and perspectives in the study.

\section{Findings}

Research Question One: What challenges do beginning secondary school teachers face in 
Ghana?

\section{1}

Thirteen (13) participants observed that compared with experienced colleagues, their workload as beginners was heavier and more difficult. Among them, about seven participants cited the number of classes, periods and the preparations involved while five participants also reported larger size of their classes the reasons why the considered their workload as heavier and more difficult. One participant stated, "The experienced teachers tend to push the larger classes to the new teachers and give them more teaching periods." Another added, "Accessing information becomes difficult as compared to the experienced teachers."

\section{2}

With respect to participants' opinions on how classification was done in their schools the responses were many and varied. Six participants thought they were given classes that were suited for them based on their specialization. Several participants noted that they were given classes that experienced teachers refused to pick. Two participants stated that they were given classes that the "experienced teachers did not pick" Another participant noted that their peers expected them to teach any class without major problems after their training as teachers.

7.3

Many participants expressed concern with classroom management issues. Twenty participants cited disrespect on the part of students as one of their main challenges in the classroom. They indicated that some of the students were noisy, less attentive in class, rude and insubordinate towards new teachers. One participant stated, "They are indiscipline (sic) and notorious." Participants also mentioned: class size, inadequate furniture and congestion as causing management/discipline problems for them. However, six participants observed that they had no problems with classroom management and discipline.

\section{4}

Majority of participants expressed difficulty with assessing students' work. Thirteen participants cited largeness of the classes they taught as a factor affecting their effective assessment of students. Three participants mentioned that marking (grading) students' work was difficult for them. "It is difficult to do constructive marking and recording marks of students." One participant stated that, "Inadequate furniture makes students to copy during class test or exercise." However, four participants indicated that they did not have any problem in assessing students.

\section{5}

Seventeen participants indicated that they encountered some difficulty associated with individual differences among students. One participant stated "The larger number of the classes I teach makes it cumbersome to attend to students individually to assist them in their learning" This sums up the opinions shared by many participants in terms of their inability to address individual differences among students. Table 1 provides a summary of responses for 
question one.

Table1: Themes for Research Question One

\begin{tabular}{l|l}
\hline Theme & \multicolumn{1}{|c}{ Description } \\
\hline 1.1 & Participants were given a heavier workload \\
1.2 & Participants expressed diverse opinions on how distribution of class was done \\
1.3 & Participants consider classroom management and discipline to be challenging \\
1.4 & Participants had difficulty with assessing students \\
1.5 & Participants had difficulty in dealing with individual differences among students \\
1.6 & Participants experienced delayed payment of salary \\
1.7 & Participants had issues with getting accommodation \\
1.8 & Participants expressed mixed reactions about their interactions with experienced \\
1.9 & colleagues \\
\hline
\end{tabular}

Research Question Two: How are beginning secondary school teachers in Ghana inducted into the profession?

\subsection{1}

More than two-thirds of participants stated they entered teaching at the secondary level without any form of formal orientation. Few participants however indicated they had some form of orientation organized for them in their schools. Two participants expressed misgivings about how the orientations were organized in this way "The orientation received as a beginning teacher was not enough; it was not properly planned."

\section{2 .2}

Five participants did not provide any response to the existence of a beginning teacher induction program in their schools. Majority of the participants were unanimous about a lack of beginning teacher induction in their schools. Some participants initially indicated they had gone through induction but it was discovered via phone interview that they rather confused student internship with induction and others misconstrued it for orientation.

\subsection{3}

On whether there were mentors for beginning teachers in their schools, five participants provided no response. More than half of participants observed that there is nothing like mentorship for beginning teachers in their schools. One participant stated: "No mentor is given and you work on your own. Much depends on your resourcefulness." A participant declared, "...mentoring is also not available after college in Ghana." Few participants revealed there are mentors in their schools but they offer services to only student teachers on internship, especially, from University of Education, Winneba. Table 2 provides a summary of themes for Research Question two. 
Table 2: Themes for Research Question Two

\begin{tabular}{l|l}
\hline Theme & \multicolumn{1}{c}{ Description } \\
\hline 2.1 & Participants reported that orientation is not usually organized for beginning teachers. \\
2.2 & Participants indicated a lack of induction program for beginning teachers. \\
2.3 & Participants lamented on lack of mentors for beginning teachers. \\
\hline
\end{tabular}

Research Question Three: What kind of support is provided to beginning secondary school teachers in Ghana?

Table 3 shows the themes that emerged from responses that related to participants' reflection on the support available to the as beginning teachers.

Table 3: Themes for Research Question Three

\begin{tabular}{l|l}
\hline Theme & \multicolumn{1}{|c}{ Description } \\
\hline 3.1 & $\begin{array}{l}\text { Participants outlined support they need from Ghana Education Service, school } \\
\text { administration, other colleague teachers and the community. }\end{array}$ \\
3.2 & $\begin{array}{l}\text { Participants indicated support received from GES, headmaster, head of department, and } \\
\text { other colleagues. }\end{array}$ \\
3.3 & Participants indicated a mixed reaction about their future in the teaching profession. \\
\hline
\end{tabular}

\section{Discussions}

\subsection{Research Question One}

This question sought to ascertain the challenges the participants faced as beginning teachers. The outcome of this question revealed that beginning teachers faced many challenges in and outside of the classroom. For instance, a majority of participants indicated the challenge of having to deal with heavy workload. In most cases, the beginning teachers were given heavier and more difficult workloads than that of their senior colleagues. Specifically, the results indicated that their workload was heavy in terms of the number of different classes (preps), sessions they taught, and the preparations involved. It also showed that their workload was difficult partly because of the large size of classes they taught. About 26 participants indicated that the student population they individually handled ranged from 100 to about 500 .

Some participants thought that experience was considered in regards to class distribution. However, in many instances, the classes that senior colleagues refused to teach were offered to the junior colleagues. Responses indicated struggles with classroom management and discipline. A critical part of the respect issues was the lack of respect on the part of students, large size of classes taught coupled with inadequate furniture in the classroom. It was also indicated that experience was important in managing students in classroom. Therefore, due to increased enrollment, inadequate classrooms, furniture and other resources, classes were normally large and sometimes overcrowded leading to classroom management issues.

Assessing students' work was also identified as a challenge to many participants. One big issue was that the classes they taught were large in size. Again, negative attitudes of 
students towards assessment were also worrisome to participants. Some participants also reported challenges grading students' classwork as they had not mastered effective assessment skills. Inadequate furniture was also seen as a factor militating against participants' effort to have effective assessment. Dealing with individual differences was also a concern to participants. A majority of participants declared their inability to deal with individuality among their students. It was indicated that the large size of classes, in addition behavior of some students, made dealing with individual differences a challenge to participants.

A major challenge that participants faced was the delay in processing and payment of salaries. It took months for participants to receive their first paycheck. A majority of participants reported waiting for more than five months to get paid and some of them had to work for a whole academic year without pay. Another challenge was in accessing accommodation facilities in the communities where the schools were located. It was noted that some school authorities did not assist participants in acquiring a place to live. However, few others helped beginning teachers with a salary advance to secure accommodation facilities.

Some participants reported that they were able to interact and share their concerns with senior colleagues while others thought that opportunities to interact and share their concerns with their experienced colleagues were minimal or non-existent. It is important for new teachers to establish a community of learners that is responsible for social and professional support in their new profession. Mulkeen, et al. (2007) rightly asserted that critical and key support for teachers that is missing in many school systems is the ongoing opportunity to talk with other professionals regarding personal challenges and professional experiences in the classroom. Inadequate teaching and learning materials, poor salary associated with teaching profession, inadequate furniture for students, lack of access to school vehicles, and lack of in-service training were also noted as challenges facing the participants.

\subsection{Research Question Two}

The objective of this question was to look at how beginning teachers were ushered into teaching especially at the secondary school level. It was revealed that despite the significance of orientation, two-thirds of participants got into active classroom teaching without any form of orientation. Evidently, the school authorities did not see the need for proper orientation as Ghana Education Service (GES) had no policy on that. While it is challenging to get into any new classroom without proper orientation, few schools organized some form orientation for their teachers. Specifically, the informal trainers went through important teaching topics that would help the beginning novice teachers. Generally, the decision to orient new teachers depends on the head teachers (Lewin \& Stuart, 2003).

Five participants did not respond to the question on induction. However, majority of the participants unanimously declared the absence of an induction program as a concept and practice in their schools. Its absence might have been the reason why some participants confused it with the internship program organized for graduating university students pursuing education. The participants were in agreement with Lewin and Stuart (2003), when they 
stated that none of the countries they studied had a policy on beginning teacher induction.

More than half of the participants indicated that they did not receive the services of mentors - they simply did not have mentors for beginning teachers in their schools. The outcome affirmed the position of Cobbold, (2007) that the practice of beginning teacher mentoring and induction is yet to be utilized in the education system in Ghana. Some schools had mentors who provided informal mentoring services to the student interns from the university's education program. However, these services were not available to the beginning teachers.

\subsection{Research Question Three}

The results showed that beginning teachers had many and varied needs and expected much from the major stakeholders of school including the Government Education Service (GES), school administration, teachers, and the community where the schools were located. This affirms the position of Killeavy (2006), that beginning teachers need support in so many areas. Though inadequate and unstructured, participants seemed to get some modicum of support from GES, their headmasters, heads of department and other colleague teacher.

The results also indicated less than one-third of participants had decided to teach for life. More than half of participants decided they would quit with one-third wanting to quit within the next five years. This finding matches the attrition rates reported by (Ingersoll \& Smith, 2004; Eaton, \& Sisson, 2008). This is disappointing since beginners usually require 3-7 years to master the skill expected of effective teachers (Alliance for Excellent Education, 2006).

\section{Conclusions}

Based on the study findings, the following conclusions can be inferred. First, beginning secondary schools teachers in the targeted schools faced many challenges including but not limited to: delayed processing and payment of salaries, heavy workload-different classes and periods taught and different preparations, teaching of large classes, difficulty with assessing students work, difficulty with classroom management and discipline, living accommodation problems, difficulty in dealing with individual differences among students. Teachers reported many concerns including, inadequate teaching and learning materials, poor salary associated, inadequate furniture, lack of access to school vehicles, lack of in-service training. This affirms the challenges that confront beginning teachers as reported by Roehrig, Pressley, \& Talotta (2002) and van Hover, \& Yeager (2004).

Second, beginning secondary school teachers in the schools targeted were not properly ushered into the teaching profession. Participants did not have access to trained mentors in their schools. This is in agreement with Cobbold (2007) and Lewin and Stuart, (2003).

Ombe, Alipio, and Nhavoto (2009) stated, "The teaching force in many Sub-Saharan Africa countries is composed of teachers of different entry qualifications who have joined the profession through multiple routes" (p.93). Majority of these teachers did not get orientation. Induction, in terms of policy and practice in the schools involved, was also clearly missing.

Third, beginning teachers expected much support and assistance from all the major 
stakeholders in education, including GES, school headmasters, department heads, other colleagues, and the entire community where the school was located. Even so, much of the support they received was informal and based on the benevolence of individuals, and thus unsustainable. This is not a good practice for the success of these teachers and the profession.

Finally, about one-third of participants intended leaving the teaching profession within the next five years because of low salaries, lack of support, and a general unattractive condition of service. Teachers make rational economic decisions about their careers and when the opportunities avail themselves, they seek different lucrative paid jobs (Mulkeen, Chapman, DeJaeghere, \& Leu, 2007). Cobbold, Ghartey, Mensah, and Ocansey (2009) note that, "There are indications that qualified teachers are deserting teaching for better paid jobs in the private sector and in Non-Governmental Organizations" (p. 78).

\section{References}

Alliance for Excellent Education (2006, February). Finding and keeping the teachers we need. (Fact sheet). Washington, D. C. Retrieved from ww.all4ed.org/files/TeacherQualityFactSheet.pdf

American Association of State Colleges and Universities (2006, October). Teacher induction programs: Trends and opportunities. Policy Matters, 3(10). Retrieved from www.aascu.org/media/pm/pdf/v3n10.pdf

American Federation of Teachers (2001, September). Beginning teacher induction: The essential bridge (Educational issues policy brief No. 13), Retrieved from www.aft.org/pubs-reports/downloads/teachers/policy13.pdf

Cobbold, C. (2007, August). Induction for teacher retention: A missing link in teacher education policy in Ghana. University of Melbourne, Faculty of Education Retrieved from www.edfac.unimelb.edu.au/research/...res/.../cosmas_cobbold.

Cobbold, C., Ghartey, J. A., Mensah, F., \& Ocansey, F. (2009). Research on education in Africa with specific reference to Ghana. In Revitalizing higher education in Sub-Saharan Africa. A United Nations University project report. United Nations University. Retrieved from: www.unu.edu/africa/files/UNU_RevitalizingHigherEducation.pdf

Eaton, E., \& Sisson, W. (2008). Why are new teachers leaving? The case for beginning teacher-induction and mentoring. Retrieved from ICF International, Presidential Transition Web site: www.icfi.com/Docs/Beginning-Teachers.pdf

Ingersoll, R. M., \& Smith, T. M. (2004). Do teacher induction and mentoring matter? AASP Bulletin, 88(638), 28-40.

Killeavy, M. (2006). Induction: A collective endeavor of learning, teaching, and leading. Theory Into Practice, 45(2), 168-176. http://dx.doi.org/10.1207/s15430421tip4502_9 
Levin, H., Belfield, C., Muennig, P., \& Rouse C. (2007, January). The cost and benefits of an excellent education for all of American children. Retrieved from: www.cbcse.org/modules/download_gallery/dlc.php?file=35

Lewin, K. M., \& Stuart, J. S. (2003, March). Researching teacher education: New Perspectives on practice, performance and policy. Multi-site teacher education research project (MUSTER) synthesis report. Brighton: Department for International Development (DFID). Retrieved from: http://www.id21.org/ed.html

Mulkeen, A., Chapman, D.W., DeJaeghere, J. G., \& Leu, E. (2007). Recruiting, retaining and retraining secondary school teachers and principals in Sub-Saharan Africa (World Bank Working Paper No. 99). Washington, D.C: The World Bank.

Odell, S. J. (2006). Designing and implementing quality mentoring programs. In Dangel, J. R. (Ed), Research on teacher induction. Teacher education year book xiv (pp. 37-66), Oxford, UK: Rowan \& Littlefield Education.

Odell, S. J., \& Huling, L. (1998). Conceptualizing quality mentoring. Retrieved from: www.pearsonschool.com/assets/.../1998_12/Odell_1.pdf

Ombe, A. Z., Alipio, J., \& Nhavoto, A. (2009). Innovation in teacher training in Sub-Saharan Africa. In Revitalizing higher education in Sub-Saharan Africa. A United Nations University project report. United Nations University. Retrieved from: www.unu.edu/africa/files/UNU_RevitalizingHigherEducation.pdf

Patten, M. L. (2nd ed.) (2001). Questionnaire Research. A Practical Guide. Los Angeles, CA: Pyrczak Publishing.

Podsen, C. J., \& Denmark, V. M. (2000). Coaching and Mentoring First-year and student teachers. Larchmont: Eye on Education.

Republic of Ghana. (1992). Constitution of the republic of Ghana. Accra: Ghana Publishing Corporation.

Roehrig, A. D., \& Pressley, M., \& Talotta, A.D. (Eds.). (2002). Stories of beginning teachers. First-year challenges and beyond. Notre Dame: University of Notre Dame.

van Hover, S., \& Yeager, E. (2004). Challenges facing beginning history teachers: An exploratory study. International Journal of Social Education, 19(1), 8-12

\section{Copyright Disclaimer}

Copyright reserved by the author(s).

This article is an open-access article distributed under the terms and conditions of the Creative Commons Attribution license (http://creativecommons.org/licenses/by/3.0/). 